\title{
PERBAIKAN ESTIMASI CURAH HUJAN BERBASIS DATA SATELIT DENGAN MEMPERHITUNGKAN FAKTOR PERTUMBUHAN AWAN
}

\section{Improvement of Rainfall Estimation Based on Satellite Data by Considering Cloud Growth Factor}

\author{
Adi Mulsandi ${ }^{1,4)^{*}}$, Mamenun ${ }^{2,4)}$, Lutfi Fitriano ${ }^{3)}$, Rahmat Hidayat ${ }^{4)}$ \\ 1) Program Studi Meteorologi, Sekolah Tinggi Meteorologi Klimatologi dan Geofisika, Jl. Perhubungan I \\ No. 5 Tangerang Selatan Banten, 15221 \\ 2) Pusat Layanan Informasi Iklim Terapan, Badan Meteorologi Klimatologi dan Geofisika, Jl. Angkasa 1 \\ No.2, Kemayoran, Jakarta Pusat, 10720 \\ 3) Sub Bidang Prediksi Cuaca, Badan Meteorologi Klimatologi dan Geofisika, Jl. Angkasa 1 No.2, \\ Kemayoran, Jakarta Pusat, 10720 \\ 4) Program Studi Klimatologi Terapan, Institut Pertanian Bogor, Jl. Raya Dramaga, Bogor, 16680 \\ *Email: adimulsandi@yahoo.com
}

\begin{abstract}
Intisari
Permasalahan utama dalam mengestimasi curah hujan menggunakan data satelit adalah kegagalan membedakan antara awan cumuliform dengan awan stratiform dimana dapat menyebabkan nilai estimasi hujan under/overestimate. Dalam penelitian ini teknik estimasi curah hujan berbasis satelit yang digunakan adalah modifikasi Convective Stratiform Technique (CSTm). CSTm memiliki kelemahan ketika harus menghitung sistem awan konveksi dengan inti konveksi yang sangat luas karena akan memiliki nilai slope parameter kecil, sehingga menghasilkan estimasi curah hujan yang underestimate. Dengan melibatkan perhitungan faktor pertumbuhan awan di algoritma CSTm permasalahan tersebut dapat diatasi. Penelitian ini menerapkan algoritma CSTm dan faktor pertumbuhan awan (CSTm+Growth Factor) untuk mengestimasi kejadian hujan lebat yang menyebabkan banjir di Jakarta pada tanggal 24 Januari 2016 yang digunakan juga sebagai studi kasus di proyek pengembangan model NWP di BMKG. Hasil penelitian menunjukan bahwa perlibatan faktor pertumbuhan awan sangat efektif memperbaiki kelemahan teknik CSTm, diperlihatkan dengan peningkatan nilai korelasi dari 0.6 menjadi 0.8 untuk wilayah Kemayoran dan 0.1 menjadi 0.83 untuk wilayah Cengkareng. Secara umum gabungan teknik CSTm dan faktor pertumbuhan awan dapat memperbaiki estimasi nilai intensitas dan fase hujan.
\end{abstract}

Kata Kunci: CSTm, Satelit, Faktor Pertumbuhan Awan, Hujan Estimasi.

\begin{abstract}
The main problem in estimating rainfall using satellite data is a failure to distinguish between cumuliform and stratiform clouds, which can cause under/overestimate of rains. In this research, the Modified Convective Stratiform Technique (CSTm) has been used to estimate rainfall based on satellite data. The weakness of the CSTm technique is defined when calculating the convective cloud system within a widely convective point. Cloud convective will have a low value of parameter slope and produce an underestimate of rainfall. This issue can be resolved by calculating the cloud growth factor on CSTm. CSTm algorithm and cloud growth factor (CSTm+Growth Factor) has been applied to this research to estimate heavy rainfall for floods event in Jakarta area on January 24th, 2016. The result showed that the cloud growth factor is very effective in improving the weakness of rainfall estimation using the CSTm technique. Correlation between estimation and observation rainfall has increased from 0,6 to 0,8 on Kemayoran and from -0,1 to 0,83 on Cengkareng. The coupled method of CSTm and cloud growth factor significantly improve in estimating phase and intensity of rainfall.
\end{abstract}

Keywords: CSTm, Satellite, Cloud Growth Factor, Rainfall Estimation.

\section{PENDAHULUAN}

Curah hujan diketahui memiliki variabilitas yang tinggi baik terhadap ruang maupun waktu (Juaeni, 2006; Kusumawati et al., 2008). Untuk dapat mengetahui variasi curah hujan di suatu wilayah dengan baik, maka di wilayah tersebut perlu penyediaan pengamatan curah hujan yang tinggi tingkat kerapatan ruang serta waktu pengamatannya. Namun di wilayah Indonesia, jumlah titik pengamatan hujan masih sangat kurang. Berdasarkan hasil kontrol kualitas data 
hujan di 162 stasiun di Indonesia, hanya 88 stasiun yang memiliki kualitas data pengamatan hujan yang baik (Supari et al, 2016). Menurut World Meteorological Organization (WMO), satu titik pengamatan curah hujan rata-rata dapat mewakili luasan area $100 \mathrm{~km}^{2}$ (WMO, 1994). Oleh karena itu, idealnya wilayah Indonesia memiliki jumlah titik pengamatan curah hujan sebanyak 1990 titik. Jumlah titik pengamatan curah hujan di Indonesia saat ini masih sangat kurang untuk dapat merespresentasikan variabilitas hujan secara spasial dengan baik.

Data sebaran curah hujan memiliki peran yang sangat penting di dalam pemodelan terutama digunakan sebagai data proksi untuk mengestimasi tiga parameter utama dalam skema parameterisasi konveksi, yaitu jumlah dan sebaran panas laten yang dilepaskan di atmosfer, fluk masa vertikal, dan organisasi konveksi secara spasial (Martin \& Scherer, 1973). Informasi data hujan sangat diperlukan dalam aktifitas kehidupan manusia karena curah hujan disamping merupakan sumber daya alam yang dibutuhkan namun juga dapat menjadi sumber bencana (Basuki et al., 2009). Sebagai sumber daya alam, curah hujan berperan antara lain untuk mendukung aktivitas pertanian, irigasi, proses produksi, dan sebagainya, sedangkan sebagai sumber bencana curah hujan berperan dalam terjadinya bencana banjir (Farida et al., 2005; Agus, 2011) atau kekeringan (Woro et al., 2009) serta berkembangnya suatu wabah penyakit (Yulia, 2012). Oleh karena itu, pengamatan hujan dengan resolusi ruang dan waktu yang baik sangat diperlukan.

Penggunaan radar cuaca dan satelit cuaca dapat dijadikan sebagai alternatif untuk mengatasi permasalahan kurangnya sebaran pengamatan data hujan. Radar cuaca mampu memberikan solusi variasi ruang dan waktu yang sangat tinggi, namun masih terdapat beberapa permasalahan seperti luas cakupan area yang masih relatif sempit dan permasalahan pada kondisi cuaca yang dapat menghasilkan propagasi anomali yaitu gejala optik pembelokan gelombang elektromagnetik radar karena adanya perbedaan densitas atmosfer.

Data satelit cuaca memang tidak mengukur curah hujan secara langsung melainkan mengukur radiasi bumi yang ditransmisikan ke luar angkasa. Namun demikian, kuatnya hubungan antara nilai radiasi awan dengan curah hujan memungkinkan estimasi hujan di suatu wilayah. Untuk mengestimasi hujan menggunakan data satelit, perlu melakukan separasi awan penghasil hujan dengan awan bukan penghasil hujan dan juga karakteristik perkembangan awan seiring bertambahnya waktu. Satelit cuaca geostasioner merupakan sateilt cuaca yang dapat digunakan untuk mengestimasi hujan tersebut.
Dalam mengestimasi curah hujan, satelit cuaca geostasioner memiliki kelebihan antara lain mampu menyediakan data estimasi curah hujan dalam skala regional (Derin dan Yilmaz, 2014; Ringard et al., 2015, 2017) dan memiliki jangkauan wilayah sangat luas dengan resolusi ruang hingga $5 \mathrm{~km}$, serta memiliki resolusi waktu yang sangat tinggi hingga 10 menit. Kelebihan tersebut juga dapat dimanfaatkan sebagai input model hidrologi yang bermasalah dengan ketidaktersediaan data pengamatan hujan (Collischonn et al., 2008; Zubieta et al., 2015, 2017). Selain itu, data estimasi hujan satelit dapat menyediakan gambaran distribusi hujan di wilayah yang tidak terjangkau pengamatan baik oleh radar maupun oleh penakar hujan seperti di tengah laut, di tengah hutan, atau di puncak gunung.

Produk estimasi curah hujan berbasis satelit biasanya menggunakan kanal inframerah yang menyediakan informasi suhu puncak awan. Nilai suhu puncak awan yang rendah diasumsikan berasosiasi dengan awan penghasil hujan. Namun, tidak semua suhu puncak awan yang dingin selalu menghasilkan hujan contohnya awan cirrus (Kidd et al., 2009), sehingga diperlukan teknik tambahan yang dapat membedakan antara awan penghasil hujan dengan awan yang tidak menghasilkan hujan.

Convective Stratiform Technique (CST) adalah metode yang dikembangkan oleh Adler \& Negri (1988) untuk memprakirakan curah hujan dengan menggunakan satelit dengan 2 tahapan utama yaitu langkah separasi dan estimasi curah hujan (Islam et al., 2002). Langkah separasi adalah langkah pemisahan awan konvektif dan awan stratiform untuk kemudian menjadi awal dari penentuan area hujan dan estimasi curah hujan pada langkah berikutnya.

Berdasarkan Islam et al., (2002), langkah separasi berawal dari penentuan Slope Parameter (S) untuk membedakan antara awan konvektif dan stratiform. Penentuan S didasarkan pada suhu puncak awan pada daerah yang akan diestimasi. Awan yang telah ditentukan jenisnya barulah dapat dimasukkan ke dalam perhitungan untuk pencarian area hujan. Nilai area hujan baik konvektif atau stratiform memiliki rumusan sama. Perbedaan rumusan yaitu pada koefisien yang digunakan untuk estimasi curah hujan dengan menggunakan area hujan yang telah ditentukan sebelumnya.

Dalam perkembangannya, metode CST mengalami tahap kembang untuk meningkatkan kemampuan metode melakukan estimasi (Endarwin et al., 2014). Hal ini dilakukan karena kondisi wilayah saat CST pertama kali dikembangkan oleh Adler \& Negri (1988) memiliki karakteristik berbeda dengan kondisi wilayah penelitian yang dilakukan saat ini. Modifikasi terhadap CST dilakukan oleh Goldenberg et al., (1990) dengan adanya perubahan terhadap nilai 
ambang batas pada proses pemisahan konvektif dan stratiform serta perubahan nilai intensitas curah hujan yang disesuaikan dengan kondisi wilayah penelitian di kawasan Laut Cina Selatan, dan penerapan nilai intensitas curah hujan (rain rate) baru pada CST yang sesuai dengan kondisi hujan di wilayah penelitian Bangladesh (Islam et al., 2002).

Penelitian yang dilakukan oleh Endarwin et al. (2014) menjelaskan adanya modifikasi yang dilakukan terhadap metode CST dengan dua modifikasi utama yaitu pada langkah pemisahan awan konvektif dan stratiform, dan penentuan estimasi curah hujan pada 23 titik di Indonesia selama empat hari pada tanggal 4 - 7 November 2011. Estimasi curah hujan yang diperoleh selanjutnya diverifikasi dengan data observasi per jam menggunakan tabel kontingensi dan nilai error (Root Mean Square Error/RMSE). Hasil penelitian tersebut menunjukkan adanya peningkatan performa metode CST yang baru dikembangkan dibandingkan dengan metode sebelumnya.

Modifikasi dilakukan terhadap nilai intensitas curah hujan dengan menggunakan nilai intensitas curah hasil penelitian Endarwin et al. (2014) di wilayah Indonesia dimana nilai intensitas curah hujan untuk stratiform adalah $0.8 \mathrm{~mm} / \mathrm{jam}$ sedangkan nilai curah hujan konvektif adalah 26 $\mathrm{mm} / \mathrm{jam}$ yang akan dimasukkan pada persamaan 3. Dalam penggunaan metode CST pada wilayah yang baru perlu dilakukan verifikasi terlebih dahulu.

Penelitian lain tentang estimasi curah hujan dengan teknik CST telah diterapkan oleh Nussi (2016) di wilayah Wamena. Hasil penerapan teknik CST di Wamena menunjukkan keakuratan tinggi pada bulan Januari, Februari dan Maret (Nussi, 2016). Selanjutnya estimasi curah hujan dengan teknik Modified Convective Stratiform Tecnique (CSTm) telah dilakukan oleh Endarwin et al. (2014). Hasil penelitian yang dilakukan pada 23 lokasi penelitian di Indonesia dengan teknik CSTm menunjukkan adanya peningkatan performa CST dibandingkan dengan metode estimasi CST sebelum dimodifikasi (Endarwin et al., 2014).

Berbeda dengan produk estimasi dan teknik estimasi lain metode CST memiliki nilai bias dan kesalahan terendah (Adler \& Negri, 1988; Negri \& Adler, 1993; Sapiano \& Arkin, 2009) serta memungkinkan jeda waktu ketersediaan estimasi yang tidak terlalu lama (Endarwin et al., 2014). Namun, metode estimasi curah hujan CST tidak dapat merepresentasikan hasil estimasi yang baik untuk semua wilayah dalam penelitian (Islam et al., 2002) karena kondisi wilayah pada saat CST pertama kali dikembangkan oleh Adler \& Negri (1988) berbeda. Pada penelitian ini akan dilakukan perbaikan estimasi curah hujan dari data satelit Himawari 8 dengan menggunakan metode CSTm yang di propose oleh Endarwin
(2014) dengan mempertimbangkan faktor pertumbuhan (growth factor) awan di wilayah Jakarta pada saat kejadian banjir tanggal 24 Januari 2016. Tanggal ini adalah tanggal yang sama yang digunakan dalam proyek penelitian pengembangan model prediksi cuaca numerik untuk kasus cuaca ekstrim yang dilakukan antara BMKG dan UK-Met office dalam proyek yang diberi judul Weather and Climate Science for Service Partnership (WCSSP) program dimana penulis juga terlibat dalam kegiatan tersebut.

\section{METODE}

Data utama yang digunakan untuk estimasi hujan pada penelitian ini adalah data satelit Himawari-8 kanal IR atau B13 dengan resolusi ruang $\pm 5 \mathrm{~km}$ yang dapat diperoleh dari server HIMAWARI-CAST STMKG. Satelit Himawari-8 adalah satelit geostasioner yang diluncurkan pada tanggal 7 Oktober 2014 dan mulai dioperasikan sejak tanggal 7 Juli 2015 oleh Badan Meteorologi Jepang (Japan Meteorogical Agency/JMA). Wilayah yang dapat diamati oleh satelit Himawari8 mencakup seluruh wilayah Indonesia, sehingga dapat dimanfaatkan untuk mendeteksi dan memantau berbagai fenomena cuaca yang terjadi di wilayah Indonesia. Satelit Himawari-8 memiliki 16 kanal panjang gelombang yang terdiri dari 3 kanal visible (VIS), 3 kanal near infrared (NIR) dan 10 kanal infrared (IR). Satelit Himawari-8 dapat menghasilkan citra setiap 10 menit untuk pengamatan global dan 2,5 menit untuk pengamatan khusus.

Kualitas hasil estimasi curah hujan dalam penelitian ini juga akan dibandingkan dengan produk estimasi curah hujan Global Satellite Mapping of Precipitation (GSMAP) untuk mengetahui potensi penggunaanya di masa yang akan datang. GSMaP adalah data curah hujan global keluaran Japan Aerospace Exploration Agency (JAXA) Precipitation Measuring Mission (PMM), beresolusi tinggi $(5 \mathrm{~km} \times 5 \mathrm{~km})$ tersedia setiap jam, memiliki latensi sekitar 4 jam dari data realtime, dan memiliki presisi tinggi yang diestimasi dari data satelit dengan menggunakan kombinasi sensor microwave (MW) dan infrared (IR) (sumber : ftp://hokusai.eorc.jaxa.jp/realtime/).

\subsection{Teknik Estimasi Curah Hujan dengan CST}

Teknik estimasi curah hujan dengan memanfaatkan citra satelit kanal IR salah satunya adalah Convective Stratiform Technique (CST). Menurut Alder \& Negri (1988), estimasi curah hujan yang berbasis data visible dan inframerah perlu memperhitungkan faktor fisis pada perhitungannya. Teknik CST merupakan teknik estimasi curah hujan yang memperhitungkan faktor fisis pada perhitungannya dengan memfokuskan masalah pada temperatur puncak awan. 
Tahap pertama yang dilakukan dalam teknik CST adalah mengidentifikasi lokasi pusat konvektif dengan memanfaatkan data suhu puncak awan Himawari-8 kanal IR1. Identifikasi pusat konvektif dilakukan dengan melihat Brigthness Temperature (BT) untuk menentukan nilai suhu terendah (Tmin).

Apabila terdapat lebih dari satu Tmin dalam satu piksel, maka dipilih yang paling dekat dengan pusat piksel. Selanjutnya nilai Tmin pada titik tersebut dilakukan perhitungan nilai slop parameter (S) dengan memperhitungkan delapan titik sekitarnya menggunakan persamaan (1).

$$
\begin{aligned}
S= & k\left(T_{i-2, j}+T_{i-1, j}+T_{i+1, j}+T_{i+2, j}+T_{i, j-2}+\right. \\
& \left.T_{i, j-1}+T_{i, j+1}+T_{i, j+2}-8 T_{i, j}\right)
\end{aligned}
$$

Dengan :

$\mathrm{i} \& \mathrm{j}=$ koordinat

$\mathrm{k}=$ konstanta pada pembagian titik di sekitar titik yang akan diprediksi, nilainya bergantung pada resolusi satelit. Pada satelit Himawari-8 dengan resolusi $4 \mathrm{~km} \times 4 \mathrm{~km}$, nilai $\mathrm{k}$ yang digunakan adalah 0.125 (Endarwin et al., 2014). Menurut Goldenberg et al. (1990) untuk membedakan apakah nilai Tmin adalah inti konvektif atau bukan, ditentukan melalui persamaan (2).

$$
S \geq \exp [0.0826(\operatorname{Tmin}-207)
$$

Jika nilai S memenuhi persamaan (2), maka Tmin tersebut merupakan inti konvektif. Untuk menentukan area hujan konvektif (Ac) menggunakan persamaan (3) (Adler \& Negri, 1988).

$\ln \left(A_{c}\right)=a T_{\min }+b$

Tabel 1. Estimasi Curah Hujan Berdasarkan Faktor Pertumbuhan Awan (Growth Factor) yang Diadopsi dari Scofield (1987).

\begin{tabular}{|c|c|c|c|c|}
\cline { 2 - 5 } \multicolumn{2}{c|}{} & \multicolumn{5}{c|}{ Hujan Estimasi } \\
\cline { 2 - 5 } \multicolumn{2}{c|}{} & \multicolumn{4}{c|}{$\Delta$ Luas piksel awan } \\
\hline $\begin{array}{c}\text { Suhu puncak } \\
\text { awan }\end{array}$ & $\begin{array}{c}>2 / \\
3\end{array}$ & $1 / 3<\Delta \mathrm{L}<2 / 3$ & $<1 /$ & Jika suhu meningkat \\
\hline$-32 \mathrm{~s} / \mathrm{d}-41^{\circ} \mathrm{C}$ & 6 & 4 & 2 & 1 \\
\hline$-41 \mathrm{~s} / \mathrm{d}-52^{\circ} \mathrm{C}$ & 13 & 8 & 4 & 2 \\
\hline$-52 \mathrm{~s} / \mathrm{d}-58^{\circ} \mathrm{C}$ & 19 & 10 & 5 & 4 \\
\hline$-58 \mathrm{~s} / \mathrm{d}-62^{\circ} \mathrm{C}$ & 25 & 15 & 8 & 5 \\
\hline$-62 \mathrm{~s} / \mathrm{d}-80^{\circ} \mathrm{C}$ & 25 & 15 & 8 & 8 \\
\hline$<-80^{\circ} \mathrm{C}$ & 50 & 25 & 15 & 10 \\
\hline
\end{tabular}

dengan a dan $b$ adalah konstanta indeks yang masing masing bernilai $-0,0492$ dan 15,27.

Untuk menentukan curah hujan dari awan kumuliform atau stratiform dari tiap grid awan dihitung dengan persamaan (4) dan (5).

Convective rainfall $(\mathrm{mm})=\mathrm{c}(\mathrm{Ac} / \mathrm{A}) \mathrm{T} . \mathrm{Rc}$

Stratiform rainfall $(\mathrm{mm})=\mathrm{s}(\mathrm{As} / \mathrm{A})$ T.Rs

Dengan:

S : Slope Parameter (Parameter penentu jenis awan)

C : jumlah sel konvektif dalam 1 grid

Ac : area hujan konvektif

A : rata-rata area yang dilingkupi oleh tiap piksel $=121\left(\mathrm{~km}^{2}\right)$

Rc : intensitas curah hujan konvektif $=20 \mathrm{~mm} / \mathrm{jam}$

$S$ : jumlah sel stratiform dalam 1 grid

As : area hujan stratiform

Rs : intensitas curah hujan stratiform $=3,5$ $\mathrm{mm} / \mathrm{jam}$

Modified Convective Stratiform Technique (CSTm) merupakan teknik estimasi curah hujan dari pengembangan teknik CST. Menurut Endarwin et al. (2014), teknik ini bertujuan untuk meningkatkan kemampuan estimasi curah hujan dari teknik CST. Pengembangan teknik CST ini didasari oleh nilai batas ambang intensitas curah hujan yang disesuaikan dengan daerah penelitian. Pada dasarnya teknik ini menggunakan perhitungan yang sama dengan metode CST, namun untuk wilayah Indonesia intensitas curah hujan konvektif (Rc) diubah menjadi $26 \mathrm{~mm} / \mathrm{jam}$ dan stratiform (Rs) menjadi 0,8 mm/jam serta untuk rata-rata area yang dilingkupi oleh tiap pixel (A) menjadi $202 \mathrm{~km}^{2}$.
$T$ : rata-rata periode (jam) 


\subsection{Growth Pertumbuhan)}

Growth factor (GF) digunakan untuk mengkuantifikasi intensitas awan konveksi yang sangat berasosiasi dengan intensitas curah hujan yang dihasilkan. GF dihitung dengan menggunakan dua citra satelit dalam dua waktu berbeda secara berurutan. Besar kecilnya growth factor ditentukan dengan perbedaan luas area piksel terhadap waktu sebelumnya. Tahapan perhitungan growth factor yaitu:

a. Tinjau nilai suhu kecerahan awan, dan beri atribut untuk setiap kondisi seperti yang tercantum dalam tabel 1.

b. Hitung luasan area piksel yang saling terkoneksi sebagai satu sistem awan untuk setiap atribut

c. Bandingkan dengan luasan sistem awan pada waktu sebelumnya

d. Jika sistem berkembang >2/3 maka disebut awan konveksi dengan intensitas tinggi.

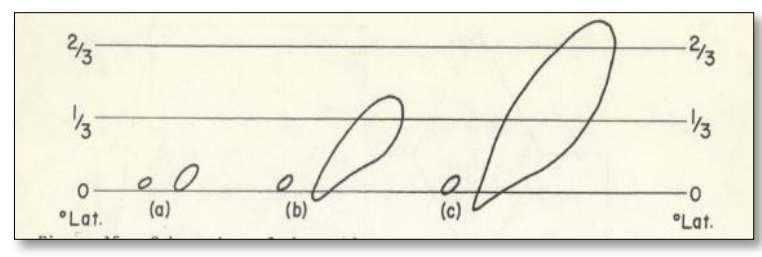

Gambar 1. Skema perhitungan area piksel terdingin dari sistem awan konvektif yang berkembang dalam setengah jam melampaui (a) $\leq 1 / 3^{\circ}$ (b) $>1 / 3^{\circ}$ tetapi $\leq 2 / 3^{\circ}$ lat; (c) $>2 / 3^{\circ}$ lat (Scofield, 1987).

\subsection{Teknik Verifikasi}

Keakuratan data estimasi curah hujan untuk penentuan teknik diverifikasi menggunakan nilai korelasi dan RMSE. Korelasi digunakan untuk mengkuantifikasi derajat hubungan linear antara hujan observasi dan hujan estimasi satelit. Semakin tinggi nilai korelasi maka semakin baik hasil estimasi curah hujannya dengan observasi.

$$
r_{x y}=\frac{\sum x y}{\sqrt{\left(\sum x^{2}\right)\left(\sum y^{2}\right)}}
$$

Keterangan:

$\mathrm{x}$ : hujan hasil estimasi

$y$ : hujan observasi

RMSE merupakan metode verifikasi yang digunakan untuk mengetahui besarnya jumlah penyimpangan antara nilai output model dibandingkan dengan nilai curah hujan aktual hasil observasi (Wilks, 1995). RMSE dirumuskan dalam persamaan (6).

$$
R M S E=\sqrt{\frac{1}{n}} \sum_{i=1}^{n}(F-O)^{2}
$$

Dengan:

$\mathrm{n}$ : banyaknya data

$F$ : Hujan hasil estimasi

$\mathrm{O}$ : Hujan observasi

Pada penelitian ini, metode RMSE digunakan untuk verifikasi dengan cara mengkuantifikasi nilai error. Dalam menentukan verifikasi, semakin besar nilai RMSE maka semakin jauh nilai estimasi curah hujan hasil masing-masing teknik terhadap nilai curah hujan observasi, dan semakin kecil nilai RMSE maka semakin baik hasil estimasi curah hujan hasil estimasi yang dikeluarkan.

Untuk mengetahui keandalan teknik estimasi juga dihitung nilai skor verifikasinya dengan tabel kontigensi multikategori guna mengukur tingkat akurasi dari estimasi curah hujan yang dihasilkan. Menurut Nurmi (2007), tabel kontingensi multikategori merupakan salah satu metode untuk menguji suatu sistem prediksi. Metode kontingensi multikategori ini digunakan untuk mengetahui ketepatan estimasi curah hujan dan sifat teknik estimasi curah hujan (underforecast/overforecast). Tabel kontingensi multikategori ditunjukkan pada Tabel 2, sedangkan untuk analisisnya dapat dilihat pada Tabel 3.

\begin{tabular}{|c|c|c|c|c|c|c|}
\hline & \multicolumn{5}{|c|}{ Observasi } \\
\hline & & $\begin{array}{l}\text { Tidak } \\
\text { Hujan }\end{array}$ & Ringan & Sedang & Lebat & $\begin{array}{l}\text { Sangat } \\
\text { Lebat }\end{array}$ \\
\hline \multirow{5}{*}{ 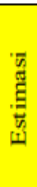 } & Tidak Hujan & $\mathrm{A}$ & B & $\mathrm{C}$ & D & E \\
\hline & Ringan & F & G & $\mathrm{H}$ & I & $\mathrm{J}$ \\
\hline & Sedang & $\mathrm{K}$ & $\mathrm{L}$ & M & $\mathrm{N}$ & 0 \\
\hline & Lebat & $P$ & Q & $\mathrm{R}$ & $S$ & $\mathrm{~T}$ \\
\hline & Sangat Lebat & $\mathrm{U}$ & V & W & $\mathrm{X}$ & $\mathrm{Y}$ \\
\hline
\end{tabular}

Tabel 2. Tabel Kontingensi Multikategori.

Tabel 3. Perhitungan Nilai Hits, False Alarms, Miss dan Correct Non-event untuk Setiap

\begin{tabular}{|c|c|}
\hline \multicolumn{2}{|r|}{ Kategori Tidak Hujan } \\
\hline Hits $=\mathrm{A}$ & False Alarms $=\mathrm{B}+\mathrm{C}+\mathrm{D}+\mathrm{E}$ \\
\hline Miss $=\mathrm{F}+\mathrm{K}+\mathrm{P}+\mathrm{U}$ & $\mathrm{CN}=\mathrm{G}+\mathrm{H}+\mathrm{I}+\mathrm{J}+\mathrm{L}+\mathrm{M}+\mathrm{N}+\mathrm{O}+\mathrm{Q}+\mathrm{R}+\mathrm{S}+\mathrm{T}+\mathrm{V}+\mathrm{W}+\mathrm{X}+\mathrm{Y}$ \\
\hline \multicolumn{2}{|r|}{ Kategori Hujan Ringan } \\
\hline Hits $=\mathrm{G}$ & False Alarms $=\mathrm{F}+\mathrm{H}+\mathrm{I}+\mathrm{J}$ \\
\hline Miss $=\mathrm{B}+\mathrm{L}+\mathrm{Q}+\mathrm{V}$ & $\mathrm{CN}=\mathrm{A}+\mathrm{C}+\mathrm{D}+\mathrm{E}+\mathrm{K}+\mathrm{M}+\mathrm{N}+\mathrm{O}+\mathrm{P}+\mathrm{R}+\mathrm{S}+\mathrm{T}+\mathrm{U}+\mathrm{W}+\mathrm{X}+\mathrm{Y}$ \\
\hline \multicolumn{2}{|r|}{ Kategori Hujan Sedang } \\
\hline Hits $=\mathrm{M}$ & False Alarms $=\mathrm{K}+\mathrm{L}+\mathrm{N}+\mathrm{O}$ \\
\hline Miss $=\mathrm{C}+\mathrm{H}+\mathrm{R}+\mathrm{W}$ & $\mathrm{CN}=\mathrm{A}+\mathrm{B}+\mathrm{D}+\mathrm{E}+\mathrm{F}+\mathrm{G}+\mathrm{I}+\mathrm{J}+\mathrm{P}+\mathrm{Q}+\mathrm{S}+\mathrm{T}+\mathrm{U}+\mathrm{V}+\mathrm{X}+\mathrm{Y}$ \\
\hline \multicolumn{2}{|r|}{ Kategori Hujan Lebat } \\
\hline Hits $=\mathrm{S}$ & False Alarms $=\mathrm{P}+\mathrm{Q}+\mathrm{R}+\mathrm{T}$ \\
\hline Miss $=\mathrm{D}+\mathrm{I}+\mathrm{N}+\mathrm{X}$ & $\mathrm{CN}=\mathrm{A}+\mathrm{B}+\mathrm{C}+\mathrm{E}+\mathrm{F}+\mathrm{G}+\mathrm{H}+\mathrm{J}+\mathrm{K}+\mathrm{L}+\mathrm{M}+\mathrm{O}+\mathrm{U}+\mathrm{V}+\mathrm{W}+\mathrm{Y}$ \\
\hline \multicolumn{2}{|r|}{ Kategori Hujan Sangat Lebat } \\
\hline Hits $=\mathrm{Y}$ & False Alarms $=\mathrm{U}+\mathrm{V}+\mathrm{W}+\mathrm{X}$ \\
\hline Miss $=\mathrm{E}+\mathrm{J}+\mathrm{O}+\mathrm{T}$ & $\mathrm{CN}=\mathrm{A}+\mathrm{B}+\mathrm{C}+\mathrm{D}+\mathrm{F}+\mathrm{G}+\mathrm{H}+\mathrm{I}+\mathrm{K}+\mathrm{L}+\mathrm{M}+\mathrm{N}+\mathrm{P}+\mathrm{Q}+\mathrm{R}+\mathrm{S}$ \\
\hline
\end{tabular}
Kategori Hujan. 
Dengan:

Hits : jumlah saat hasil estimasi "yes" dan hasil observasi "yes"

False Alarms: jumlah saat hasil estimasi "yes" dan hasil observasi "no"

Missed Events: jumlah saat hasil estimasi "no" dan hasil observasi "yes"

Correct non-event: jumlah saat hasil estimasi "no" dan hasil observasi "no"

Untuk menganalisis tabel kontingensi dapat menggunakan scoring Percent Correct (PC) atau Frequency Bias Index (FBI).

\section{a. Percent Correct (PC)}

Merupakan perhitungan akurasi sederhana untuk semua estimasi. PC dapat menjawab secara keseluruhan berapa besar estimasi yang bernilai benar. Nilai tinggi digunakan untuk kasus yang banyak mengestimasikan kejadian umum. Namun PC tidak dapat digunakan untuk verifikasi kejadian eskstrim. Jangkauan untuk PC antara 0 hingga 1. Semakin mendekati 1 maka semakin sempurna. Untuk menghitung nilai PC dapat dengan menggunakan persamaan (7).

$$
P C=\frac{\text { Hits }+ \text { Correct Negatives }}{\text { Total }}
$$

\section{b. Frequency Bias Index (FBI)}

$\mathrm{FBI}$ merupakan perhitungan yang digunakan untuk menghitung kejadian overestimate dan underestimate. Jangkauan nilainya antara nol sampai tak berhingga. Bila nilai FBI lebih besar dari 1, maka estimasi yang dihasilkan cenderung overestimate. Bila nilai FBI kurang dari 1, maka estimasi yang dihasilkan cenderung underestimate. Semakin mendekati 1 maka semakin sempurna. Persamaan (8) merupakan rumusan $\mathrm{FBI}$.

$$
F B I=\frac{\text { Hits }+ \text { false Alarm }}{\text { HIts }+ \text { Misses }}
$$

\section{HASIL DAN PEMBAHASAN}

\subsection{Curah Hujan Hasil Pengukuran AWS}

Pada tanggal 24 Januari 2016 sekitar pukul 22.00 WIB, wilayah Jakarta dilanda banjir setelah sebelumnya terjadi hujan lebat. Berdasarkan laporan BNPB (2016) lokasi banjir pada tanggal 24 Januari 2016 meliputi wilayah Jakarta bagian utara baik sebelah barat maupun sebelah timur. Secara lengkap lokasi banjir dapat dilihat pada Gambar 2.

Berdasarkan pantauan alat penakar curah hujan pada dua lokasi yang mewakili kejadian banjir yaitu satsiun meteorologi Cengkareng dan stasiun meteorologi Kemayoran memperlihatkan adanya kejadian hujan lebat dan sedang sekitar pukul 22.00 WIB dengan intensitas masingmasing sebesar $49 \mathrm{~mm} / 3 \mathrm{jam}$ dan $13.6 \mathrm{~mm} / 3 \mathrm{jam}$. Histogram kejadian curah hujan untuk setiap tiga jam di kedua lokasi ditunjukkan pada Gambar 3.

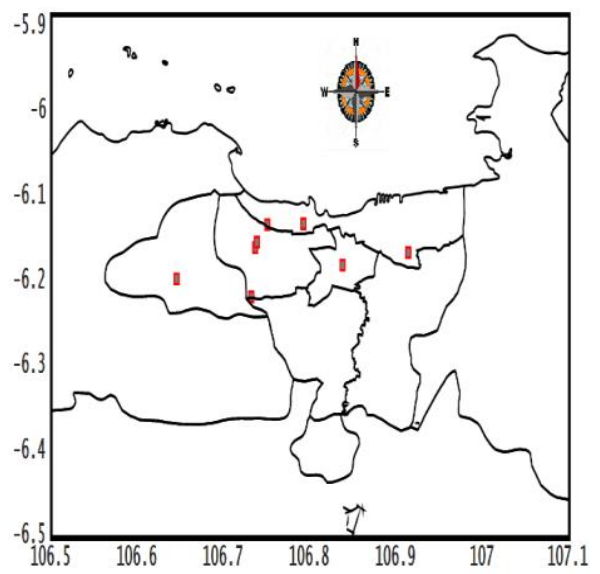

Gambar 2. Lokasi banjir di Jakarta pada tanggal 24 Januari 2016. Kotak warna merah menunjukan titik lokasi terjadinya banjir berdasarkan catatan BNPB (2016).

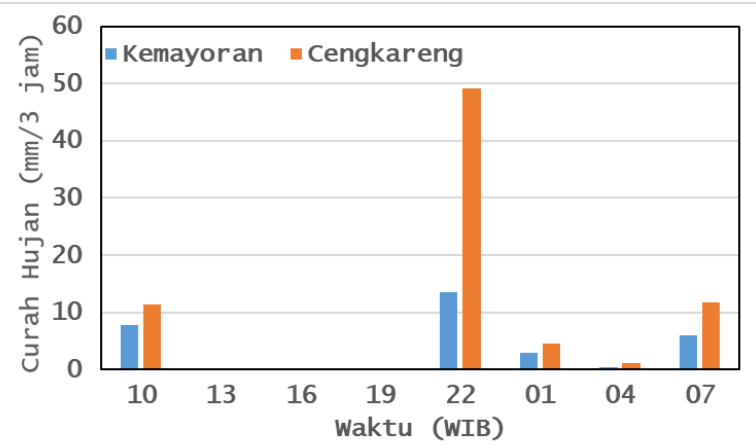

Gambar 3. Curah Hujan pada tanggal 24 Januari 2016 di dua lokasi yang terdampak banjir.

\subsection{Estimasi Hujan dengan Data Satelit Himawari-8 \\ Estimasi curah hujan untuk satu titik setiap} jam diakumulasi selama tiga jam jam untuk memperoleh curah hujan per tiga jam, selama 24 jam pada saat kejadian banjir. Estimasi curah hujan per tiga jam kemudian dibandingkan dengan data pengamatan BMKG untuk rentang waktu yang sama.

\subsubsection{Estimasi CH Dengan Persamaan CSTm}

Perbandingan antara curah hujan hasil estimasi teknik CSTm dan curah hujan pengamatan AWS per-tiga jam di Cengkareng diperlihatkan pada Gambar 4. 


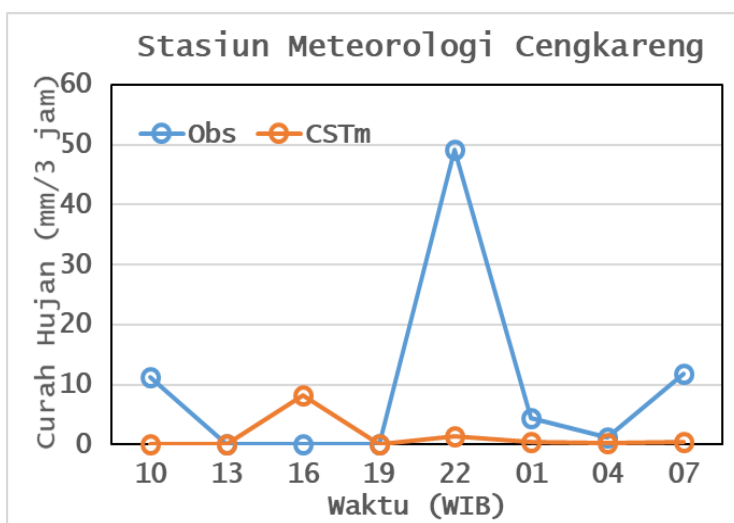

(a)

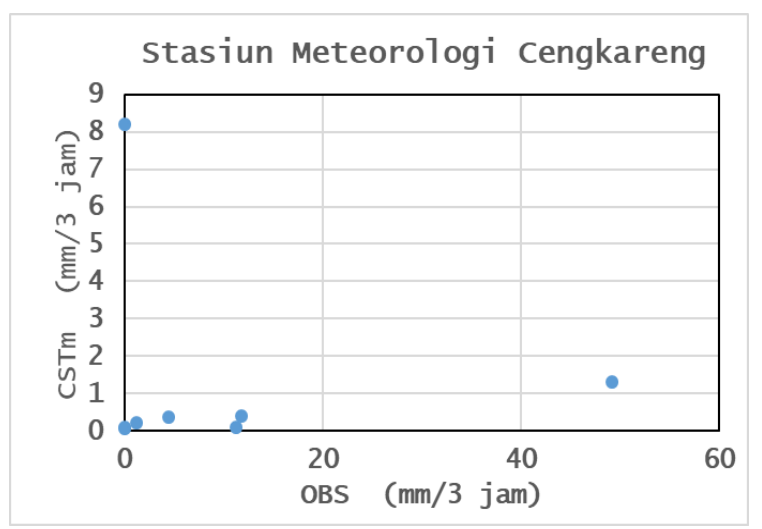

(b)

Gambar 4. Perbandingan antara $\mathrm{CH}$

pengamatan harian dan $\mathrm{CH}$ estimasi dengan teknik CSTm per-tiga jam: a) plot time series dan b) scatter plot.

Scatter plot antara $\mathrm{CH}$ pengamatan dan $\mathrm{CH}$ estimasi (Gambar 4.b) menunjukkan bahwa estimasi dengan menggunakan teknik CSTm menghasilkan jumlah curah hujan yang lebih kecil dari pengamatan (underestimate). Menurut laporan BNPB kejadian banjir didahului dengan hujan lebat. Hal ini sesuai dengan hasil penakaran curah hujan di stasiun meteorologi Cengkareng di lokasi sekitar kejadian yaitu sebagian besar wilayah Jakarta Barat dan perbatasan dengan Tangerang dimana hujan tercatat $49 \mathrm{~mm} / 3$ jam yang masuk dalam kategori hujan lebat. Sementara hasil estimasi curah hujan dengan teknik CSTm hanya menghasilkan hujan di bawah $1 \mathrm{~mm}$ dalam hal ini bisa dikatakan teknik CSTm gagal mengestimasi kejadian curah hujan lebat. Nilai korelasi juga menunjukan nilai yang sangat rendah yaitu $-0,1$.

Hasil yang berbeda ditunjukan pada titik pengamatan yang lain yaitu stasiun meteorologi Kemayoran. Perbandingan antara curah hujan hasil estimasi teknik CSTm dan curah hujan pengamatan permukaan per-tiga jam di stasiun meteorologi Kemayoran diperlihatkan pada Gambar 5.

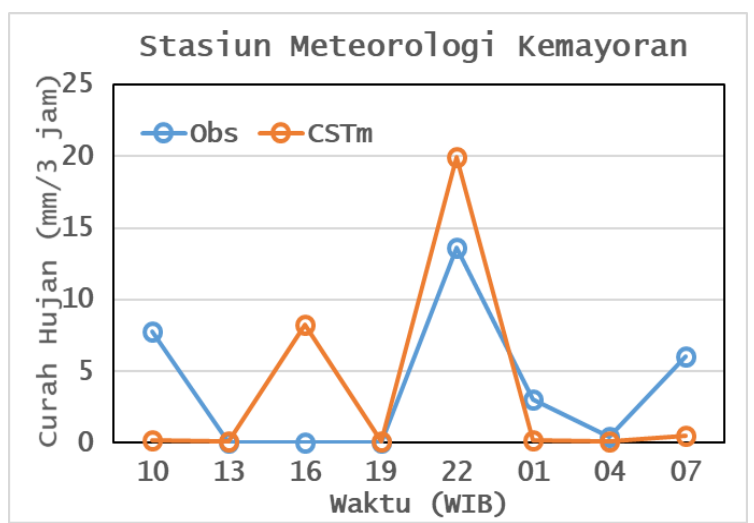

(a)

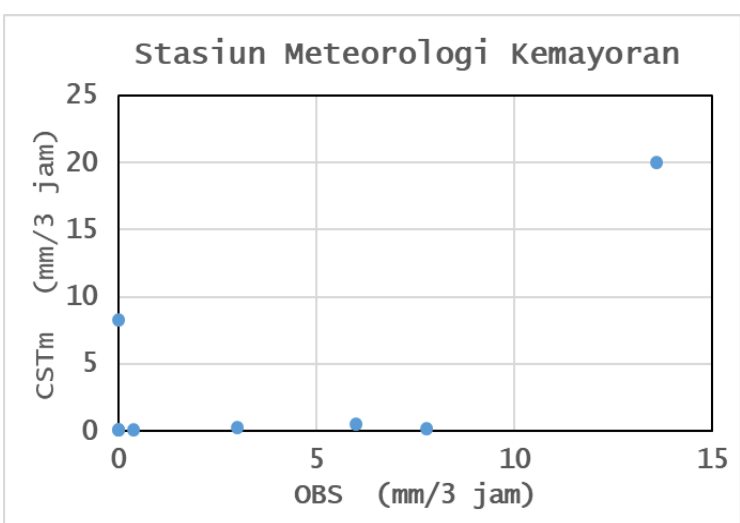

(b)

Gambar 5. Perbandingan antara $\mathrm{CH}$ pengamatan harian dan $\mathrm{CH}$ estimasi dengan teknik CSTm per-jam: a) plot time series dan b) scatter plot.

Scatter plot antara $\mathrm{CH}$ pengamatan dan $\mathrm{CH}$ estimasi (Gambar 5.b) menunjukkan bahwa estimasi dengan menggunakan teknik CSTm menghasilkan jumlah curah hujan yang lebih kecil dari pengamatan (underestimate). Hasil penakaran curah hujan stasiun Meteorologi Kemayoran di lokasi sekitar kejadian banjir yaitu Jakarta Utara hujan tercatat $13.6 \mathrm{~mm} / 3$ jam yang masuk dalam kategori hujan sedang. Sementara hasil estimasi curah hujan dengan teknik CSTm menghasilkan hujan yang lebih tinggi yaitu 19 $\mathrm{mm} / 3$ jam. Nilai korelasi menunjukan nilai yang cukup baik yaitu 0,6 .

\subsubsection{Estimasi Curah Hujan CSTm dengan Mempertimbangkan Growth Factor Awan (CSTm+Growth Factor)}

Perbandingan antara curah hujan hasil estimasi satelit CSTm+Growth Factor dan curah hujan pengamatan setiap tiga jam di stasiun Meteorologi Cengkareng diperlihatkan pada Gambar 6. 


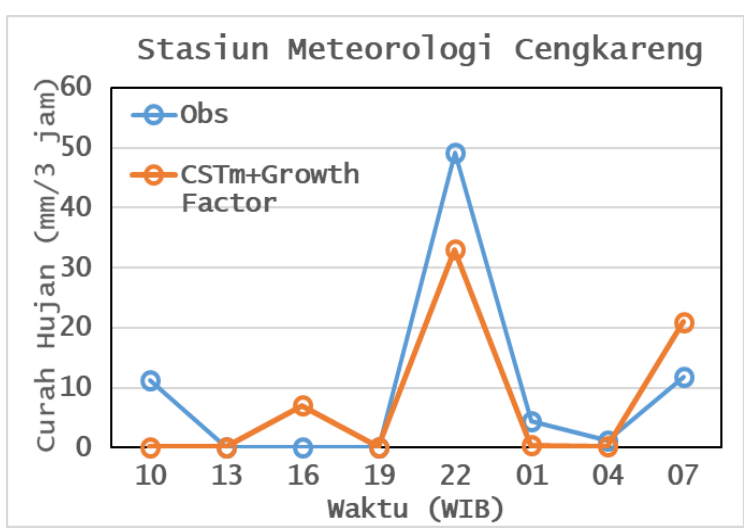

(a)

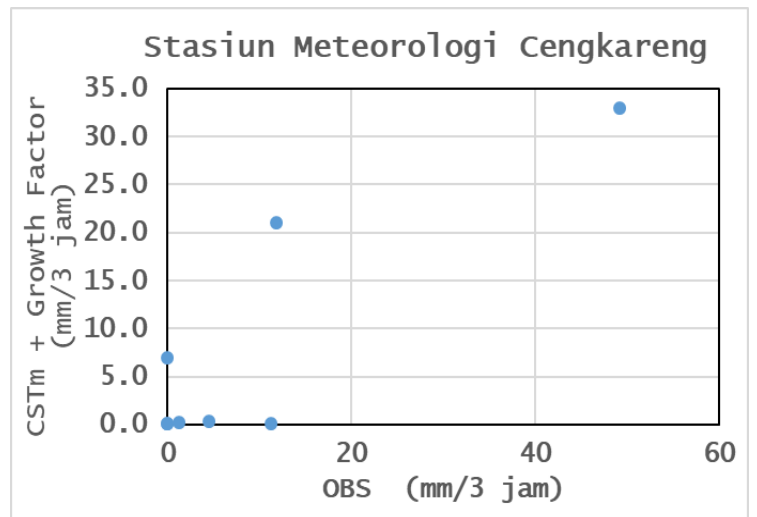

(b)

Gambar 6. Perbandingan antara $\mathrm{CH}$ pengamatan harian dan $\mathrm{CH}$ estimasi satelit dengan mempertimbangkan GF per-tiga jam: a) plot time series dan b) scatter plot.

Scatter plot antara $\mathrm{CH}$ pengamatan dan $\mathrm{CH}$ estimasi (Gambar 6.b) menunjukkan bahwa estimasi satelit CSTm+Growth Factor menghasilkan jumlah curah hujan yang lebih mendekati $\mathrm{CH}$ dari pengamatan. Berdasarkan perhitungan CSTM+Growth Factor, curah hujan di Cengkareng terestimasi $49 \mathrm{~mm} / 3$ jam yang masuk dalam kategori hujan lebat. Nilai korelasi juga menunjukan nilai yang cukup baik yaitu 0,86 dengan nilai RMSE $9.5 \mathrm{~mm}$.

Selanjutnya untuk mengetahui tingkat akurasi dari teknik estimasi satelit CSTm +Growth Factor awan diverifikasi terhadap data curah hujan dari hujan pengamatan, menggunakan metode verifikasi multikategori (Tabel 4) guna mencari nilai Percent Correct (PC) dan Frequency Bias Index (FBI).

Dalam studi kasus ini tidak terdapat kejadian hujan sangat lebat sehingga tidak ada analisis pada kategori ini. Berdasarkan analisis tabel kontingensi (Tabel 5) dapat diketahui kemampuan teknik CSTm+ Growth Factor dalam menentukan nilai estimasi curah hujan di Cengkareng. Teknik CSTm+ Growth Factor dapat mendeteksi satu kejadian hujan lebat dengan akurat, hal ini terlihat dari nilai FBI yang bernilai 1 dan $100 \%$. Estimasi terjadinya hujan lebat bernilai benar, hal ini ditunjukkan oleh nilai PC yang bernilai 1 .

Untuk kejadian hujan dengan intensitas sedang, kemampuan teknik CSTm+Growth Factor juga sangat baik hal ini terbukti dari nilai FBI yang menunjukkan nilai 1 dengan $100 \%$ estimasi terjadinya hujan dengan intensitas sedang bernilai benar. Pada kejadian hujan ringan estimasi dari teknik CSTm+Growth Factor menunjukkan kemampuan yang cenderung underestimate, hal ini diketahui dari hasil FBI yang menunjukkan nilai 0.7 , dan estimasi terjadinya hujan dengan intensitas ringan $60 \%$ bernilai benar, hal ini ditunjukkan oleh nilai PC sebesar 0,6 . Untuk kejadian tidak hujan teknik ini menunjukkan kemampuan estimasi yang cenderung overestimate, hal ini dibuktikan dengan nilai FBI yang bernilai 1,3 , dan $60 \%$ kejadian tidak hujan yang diestimasikan bernilai benar, hal ini diketahui dari nilai PC yang menunjukkan nilai 0.6.

Tabel 4. Tabel Kontingensi Multikategori Hasil Uji Kemampuan Teknik CSTm + Growth Factor.

\begin{tabular}{|c|c|c|c|c|c|c|c|}
\hline & & \multicolumn{5}{|c|}{ Obs Cengkareng } & \multirow{2}{*}{$\begin{array}{l}\text { Jumlah } \\
\text { Estimasi }\end{array}$} \\
\hline & & Tidak hujan & Ringan & Sedang & Lebat & Sangat lebat & \\
\hline \multirow{5}{*}{$\underset{\text { GF }}{\mathrm{CSTm}+}$} & Tidak hujan & 2 & 2 & 0 & 0 & 0 & 4 \\
\hline & Ringan & 1 & 1 & 0 & 0 & 0 & 2 \\
\hline & Sedang & 0 & 0 & 1 & 0 & 0 & 2 \\
\hline & Lebat & 0 & 0 & 0 & 1 & 0 & 0 \\
\hline & Sangat lebat & 0 & 0 & 0 & 0 & 0 & 0 \\
\hline \multicolumn{2}{|c|}{ Jumlah Obs } & 3 & 3 & 2 & 0 & 0 & 8 \\
\hline
\end{tabular}

Tabel 5. Hasil Analisis Tabel Kontingensi Uji Kemampuan Teknik CSTm + Growth Factor.

\begin{tabular}{|c|c|c|c|c|c|}
\hline Analisis & Tidak hujan & Ringan & Sedang & Lebat & Sangat lebat \\
\hline PC & 0.6 & 0.6 & 1 & 1 & - \\
\hline FBI & 1.3 & 0.7 & 1 & 1 & - \\
\hline
\end{tabular}


Perbandingan antara curah hujan hasil estimasi satelit CSTm dengan mempertimbangkan faktor pertumbuhan awan dan curah hujan pengamatan AWS per-tiga jaman di Kemayoran diperlihatkan pada Gambar 7.

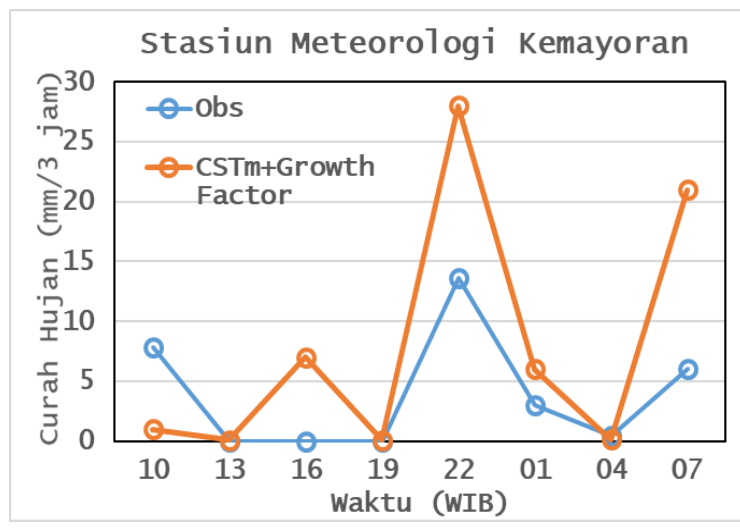

(a)

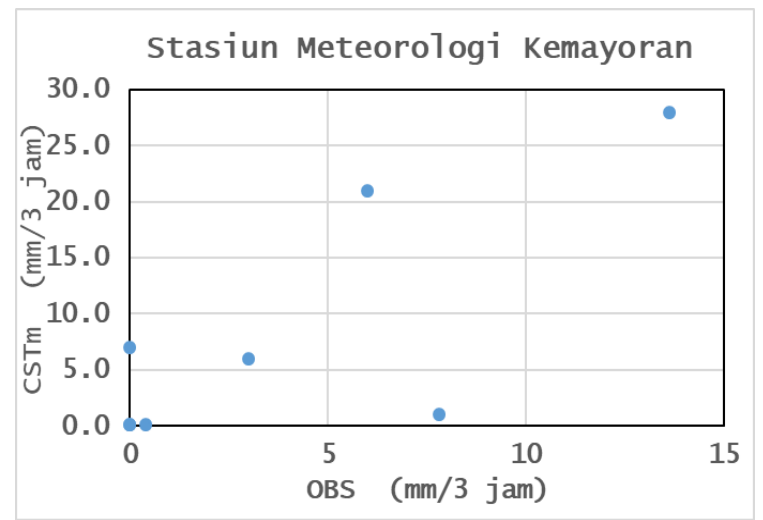

(b)

Gambar 7. Perbandingan antara $\mathrm{CH}$ pengamatan harian dan $\mathrm{CH}$ estimasi dengan teknik CSTm perjam: a) plot time series dan b) scatter plot.
Scatter plot antara $\mathrm{CH}$ pengamatan dan $\mathrm{CH}$ estimasi (Gambar 7.b) menunjukkan bahwa estimasi satelit CSTm dengan mempertimbangkan growth factor awan menghasilkan jumlah curah hujan yang lebih mendekati $\mathrm{CH}$ dari pengamatan. Berdasarkan perhitungan CSTm+Growth Factor, curah hujan di Kemayoran terestimasi $28 \mathrm{~mm} / 3$ jam yang masuk dalam kategori hujan lebat. Nilai korelasi juga menunjukan nilai yang cukup baik yaitu 0,8 dengan nilai RMSE $8.2 \mathrm{~mm}$.

Untuk wilayah Kemayoran tidak terdapat kejadian hujan lebat dan sangat lebat sehingga tidak ada analisis pada kategori ini. Berdasarkan analisis tabel kontingensi (Tabel 7) dapat diketahui kemampuan teknik CSTm+ Growth Factor dalam menentukan nilai estimasi curah hujan di Kemayoran. Pada kejadian hujan sedang estimasi dari teknik CSTm+Growth Factor menunjukkan kemampuan yang cenderung overestimate yang diketahui dari hasil FBI yang menunjukkan nilai lebih dari satu yaitu 3 , dan estimasi terjadinya hujan dengan intensitas sedang $80 \%$ bernilai benar hal ini ditunjukkan oleh nilai PC sebesar 0,8 .

Pada kejadian hujan ringan estimasi dari teknik CSTm+Growth Factor menunjukkan kemampuan yang cenderung underestimate yang diketahui dari hasil FBI yang menunjukkan nilai 0.7 , dan estimasi terjadinya hujan dengan intensitas ringan $90 \%$ bernilai benar hal ini ditunjukkan oleh nilai PC sebesar 0,9. Untuk kejadian tidak hujan teknik ini menunjukkan kemampuan estimasi yang cenderung underestimate hal ini dibuktikan dengan nilai FBI yang bernilai 0,8 dan $90 \%$ kejadian tidak hujan yang diestimasikan bernilai benar. Hal ini diketahui dari nilai PC yang menunjukkan nilai 0.9.

Tabel 6. Hasil Analisis Tabel Kontingensi Uji Kemampuan Teknik CSTm + Growth Factor.

\begin{tabular}{|c|c|c|c|c|c|c|c|}
\hline & & \multicolumn{5}{|c|}{ Obs Kemayoran } & \multirow{2}{*}{$\begin{array}{c}\text { Jumlah } \\
\text { Estimasi }\end{array}$} \\
\hline & & Tidak hujan & Ringan & Sedang & Lebat & Sangat lebat & \\
\hline \multirow{5}{*}{ CST } & Tidak hujan & 3 & 0 & 0 & 0 & 0 & 3 \\
\hline & Ringan & 0 & 2 & 0 & 0 & 0 & 2 \\
\hline & Sedang & 1 & 1 & 1 & 0 & 0 & 3 \\
\hline & Lebat & 0 & 0 & 0 & 0 & 0 & 0 \\
\hline & Sangat lebat & 0 & 0 & 0 & 0 & 0 & 0 \\
\hline \multicolumn{2}{|c|}{ Jumlah Obs } & 4 & 3 & 1 & 0 & 0 & 8 \\
\hline
\end{tabular}

Tabel 7. Hasil Analisis Tabel Kontingensi Uji Kemampuan Teknik CSTm + Growth Factor.

\begin{tabular}{|c|c|c|c|c|c|}
\hline & Tidak hujan & Ringan & Sedang & Lebat & Sangat lebat \\
\hline PC & 0.9 & 0.9 & 0.8 & - & - \\
\hline FBI & 0.8 & 0.7 & 3.0 & - & - \\
\hline
\end{tabular}




\subsubsection{Analisis}

Dari hasil perbandingan hasil estimasi curah hujan dengan mempertimbangkan Growth Factor awan menghasilkan estimasi curah hujan yang jauh lebih mendekati dengan hasil pengukuran oleh AWS. Sebaliknya hasil estimasi curah hujan dengan menggunakan teknik CSTm memperlihatkan nilai estimasi yang sangat underestimate. Hal ini sangat mudah dijelaskan karena dasar perhitungan estimasi curah hujan dengan CSTm adalah berdasarkan nilai slope awan.

Karakteristik nilai slope awan sangat dipengaruhi oleh variasi nilai brightness temperature di titik grid yang dilibatkan dalam perhitungannya. Dalam perhitungan slope awan ketika nilai variasinya kecil maka nilai slope juga akan kecil. Untuk nilai slope parameter pada area inti awan konvektif yang sangat luas akan menghasilkan nilai slope parameter yang sangat kecil sehingga akan ditinjau sebagai awan stratriform dimana awan ini berasosiasi dengan curah hujan dengan intensitas ringan. Sehingga curah hujan hasil perhitungan dengan teknik CSTm akan cenderung underestimate di wilayah inti konveksi seperti yang terlihat dalam Gambar 7 .

Teknik CSTm akan efektif hanya pada area batas awan yang memperlihatkan variasi nilai kecerahan suhunya tinggi atau maksimum karena karakteristik tekstur awan di bagian batas adalah sangat kasar sehingga memiliki nilai slope parameter yang besar dimana nilai slope parameter yang besar berasosiasi dengan awan konvektif yang menghasilkan hujan lebat.

\subsubsection{Perbandingan Hujan dengan Growth Factor dan Hujan GSMAP}

Produk estimasi curah hujan GSMAP memiliki latensi ketersediaan data empat jam, sehingga monitoring kejadian hujan secara real time tidak dapat dilakukan. Oleh karena itu, usaha secara mandiri untuk menyediakan data estimasi hujan berbasis data satelit perlu diupayakan untuk menyediakan data monitoring secara real time. Gambar 8 memperlihatkan perbandingan antara produk estimasi curah hujan dengan GF dibandingkan dengan produk estimasi hujan dari GSMAP pada pukul 22.00 WIB ketika hujan lebat pemicu banjir terjadi.

Berdasarkan Gambar 9, dapat ditunjukkan bahwa GSMAP dan CSTm+Growth Factor mampu menangkap curah hujan lebat dengan baik di lokasi kejadian pada pukul 22.00 WIB dimana banjir dilaporkan terjadi. Namun demikian, hasil estimasi hujan dengan CSTm+Growth Factor lebih representatif karena memiliki area hujan lebat yang lebih luas jika dipertimbangakan dengan sebaran wilayah banjir dari BNPB. Estimasi curah hujan dengan CSTm+Growth Factor sangat menguntungkan karena dengan mengkuantifikasi faktor pertumbuhan awan dapat meningkatkan akurasi estimasi curah hujan.

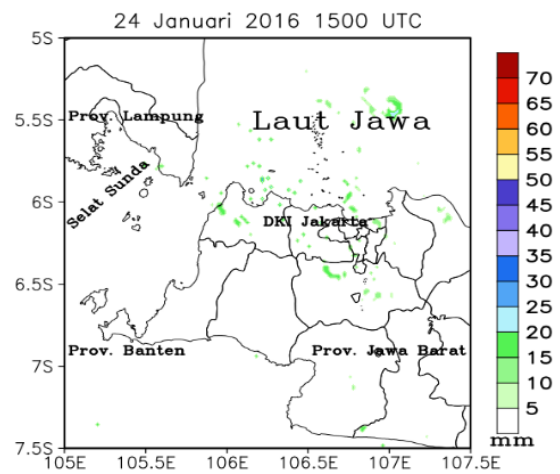

Gambar 8. Hasil estimasi hujan pada saat kejadian hujan lebat pemicu banjir tanggal 24 Januari 2016 pukul 22.00 WIB menggunakan teknik CSTm.

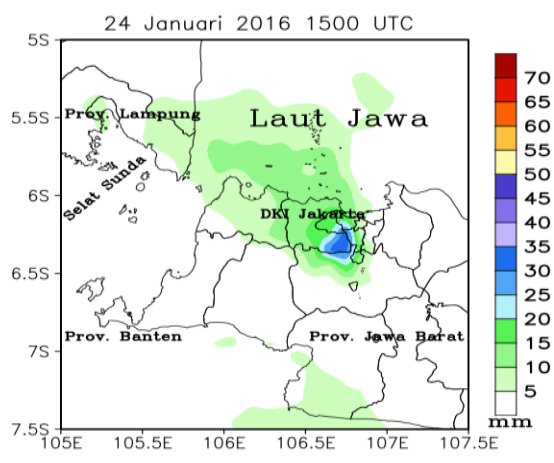

(a)

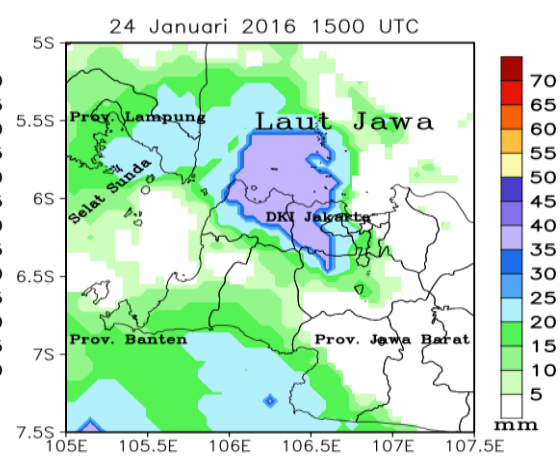

(b)

Gambar 9. Hasil estimasi hujan pada saat kejadian hujan lebat pemicu banjir tanggal 24 Januari 2016 pukul 22.00 WIB: (a) curah hujan GSMAP (b) curah hujan CSTm+Growth Factor 


\section{KESIMPULAN}

Dalam artikel ini diperkenalkan teknik estimasi hujan dengan mempertimbangkan growth factor awan. Melalui teknik ini permasalahan utama dalam metode estimasi hujan berbasis data satelit yaitu kegagalan membedakan jenis awan penghasil hujan dapat teratasi. Metode Growth Factor melengkapi referensi teknik estimasi curah hujan yang sudah ada sebelumya.

Dalam kajian ini juga membandingkan teknik Growth Factor dengan salah satu teknik estimasi hujan berbasis data satelit yang telah ada sebelumnya yaitu CSTm dimana teknik ini memiliki kekurangan dalam hal penentuan jenis awan penghasil hujannya karena hanya mengandalkan perhitungan slope awan. Perhitungan slope awan sangat bergantung pada nilai variasi suhu pada semua titik grid yang digunakan dalam perhitungan. Oleh karena itu teknik CSTm tidak dapat bekerja dengan baik pada sistem awan yang memiliki inti awan sangat luas. Inti awan yang sangat luas akan memiliki nilai slope kecil sehingga dalam teknik CSTm akan ditinjau sebagai awan stratiform yang menghasilkan hujan dengan intensitas rendah, sehingga teknik CSTm akan menghasilkan estimasi yang underestimate.

Penggunaan growth factor dapat mengatasi permasalahan underestimate yang pada umumnya dihadapi oleh teknik estimasi satelit sebelumnya. Dalam kajian ini teknik tersebut mampu meningkatkan nilai korelasi dari 0,6 menjadi 0,8 di lokasi Kemayoran dan dari -0,1 menjadi 0,86 di lokasi Cengkareng. Hasil tersebut cukup menjanjikan untuk dapat digunakan dalam operasional monitoring cuaca.

\section{DAFTAR PUSTAKA}

Adler, R.F., Negri, A.J. (1988). A Satellite Infrared Technique to Estimate Tropical Convective and Stratiform Rainfall. Journal of Applied Meteorology, 27(1), 30-51. doi: 10.1175/15200450(1988)027<0030:ASITTE>2.0.CO;2

BPBD.

https://www.liputan6.com/news/read/24198 69/titik-banjir-di-ibu-kota-kelapa-gadingtergenang-10-cm. Diakses tanggal 1 Oktober 2019.

Collischonn, B., Collischonn, W., Tucci, C.E.M. (2008). Daily Hydrological Modeling in the Amazon Basin Using TRMM Rainfall Estimates. Journal of Hydrology, 360(1-4), 207-216. doi: 10.1016/j.jhydrol.2008.07.032

Derin, Y., Yilmaz, K.K. (2014). Evaluation of Multiple Satellite-Based Precipitation Products over Complex Topography.
Journal of Hydrometeorology, 15(4), 14981516. doi: 10.1175/JHM-D-13-0191.1

Endarwin., Hadi, S., Tjasyono, H.K.B., Gunawan, D., Siswanto. (2014). Modified Convective Stratiform Technique (CSTm) Performance on Rainfall Estimation in Indonesia, Journal of Mathematical and Fundamental Sciences, Vol 46(3), 251-268. doi: 10.5614/j.math.fund.sci.2014.46.3.4

Goldenberg, S.B., Houze, Jr., R.A., Churchill, D.D. (1990). Convective and Stratiform Components of a Winter Monsoon Cloud Cluster Determined from Geosynchronous Infrared Satellite Data. Journal of The Meteorological Society of Japan, 68(1), 3763. doi: 10.2151/jmsj1965.68.1_37

Islam, Md.N., Islam, A.K.M.S., Hayashi, T., Terao, T., Uyeda, H. (2002). Application of a Method to Estimate Rainfall in Bangladesh Using GMS5 Data. Journal of Natural Disaster Science, 24(2), 83-89.

Juaeni, I., (2006). Analisis Variabilitas Curah Hujan Wilayah Indonesia Berdasarkan Pengamatan Tahun 1975-2004. Jurnal Matematika, 9(2), 171-180.

Kidd, C., Kniveton, D.R., Todd, M.C., Bellerby, T.J. (2003). Satellite Rainfall Estimation Using Combined Passive Microwave and Infrared Algorithms. Journal of Hydrometeorology, 4(6), 1088-1104. doi: $10.1175 / 1525-$

7541(2003)004<1088:SREUCP>2.0.CO;2

Kusumawati, Y., Effendy, S., Aldrian, E. (2008). Variasi Spasial dan Temporal Hujan Konvektif di Pulau Jawa Berdasarkan Citra Satelit. Jurnal Agromet Indonesia, 22(1).

Martin, D.W., Scherer, W.D. (1973). Review of Satellite Rainfall Estimation Methods. Bulletin of the American Meteorological society, 54(7), 661-675. doi: 10.1175/15200477-54.7.661

Negri, A.J., Adler, R.F. (1993). An Intercomparison of Three Satellite Infrared Rainfall Techniques over Japan and Sourrounding Waters. Journal of Applied Meteorology, 32(2), 357-373. doi: 10.1175/15200450(1993)032<0357:AIOTSI>2.0.CO;2

Ringard, J., Becker, M., Seyler, F., Linguet, L. (2015). Temporal and Spatial Assessment of Four Satellite Rainfall Estimates over French Guiana and North Brazil. Remote Sensing, 7(12), 16441-16459. doi: 10.3390/rs71215831

Ringard, J., Seyler, F., Linguet, L. (2017). A Quantile Mapping Bias Correction Method Based on Hydroclimatic Classification of the Guiana Shield. Sensors, 17(6), 1413. doi: 10.3390/s17061413

Sapiano, M.R.P., Arkin, P.A. (2009), An Intercomparison and Validation of HighResolution Satellite Precipitation Estimates 
with 3-Hourly Gauge Data. Journal of Hydrometeorology, 10(1), 149-166. doi: 10.1175/2008JHM1052.1

Scofield, R.A. (1987). The NESDIS Operational Convective Precipitation-Estimation Technique. Monthly Weather Review, 115(8), 1773-1792. doi: 10.1175/15200493(1987)115\%3C1773:TNOCPE\%3E2.0 $\mathrm{CO} ; 2$

Supari, Tangang, F., Juneng, L., Aldrian, E. (2016). Observed Changes in Extreme Temperature and Precipitation over Indonesia. International Journal of Climatology, 37(4), 1979-1997. doi: $10.1002 /$ joc. 4829

WMO. (1994). Guide to Hydrological Practices: Data Acquisition and Processing, Analysis, Forecasting and Other Applications. WMO
Guideline

No.

168. http://www.innovativehydrology.com/WMONo.168-1994.pdf

Zubieta, R., Getirana, A., Espinoza, J.C., Lavado, W. (2015). Impacts of Satellite-Based Precipitation Datasets on Rainfall-Runoff Modeling of the Western Amazon Basin of Peru and Ecuador. Journal of Hydrology, 528 599-612. 10.1016/j.jhydrol.2015.06.064

Zubieta, R., Getirana, A., Espinoza, J.C., LavadoCasimiro, W., Aragon, L. (2017). Hydrological Modeling of the PeruvianEcuadorian Amazon Basin Using GPMIMERG Satellite-Based Precipitation Dataset. Hydrology and Earth System Sciences, 21(7), 3543-3555. doi: 10.5194/hess-21-3543-2017 